Document downloaded from:

http://hdl.handle.net/10251/121081

This paper must be cited as:

Arnal Arnal, JM.; García-Fayos, B.; Sancho, M. (2018). Application of ultrafiltration for drinking water production in decentralised systems: 20 years of the AQUAPOT project. Desalination and Water Treatment. 103:296-306. https://doi.org/10.5004/dwt.2018.21989

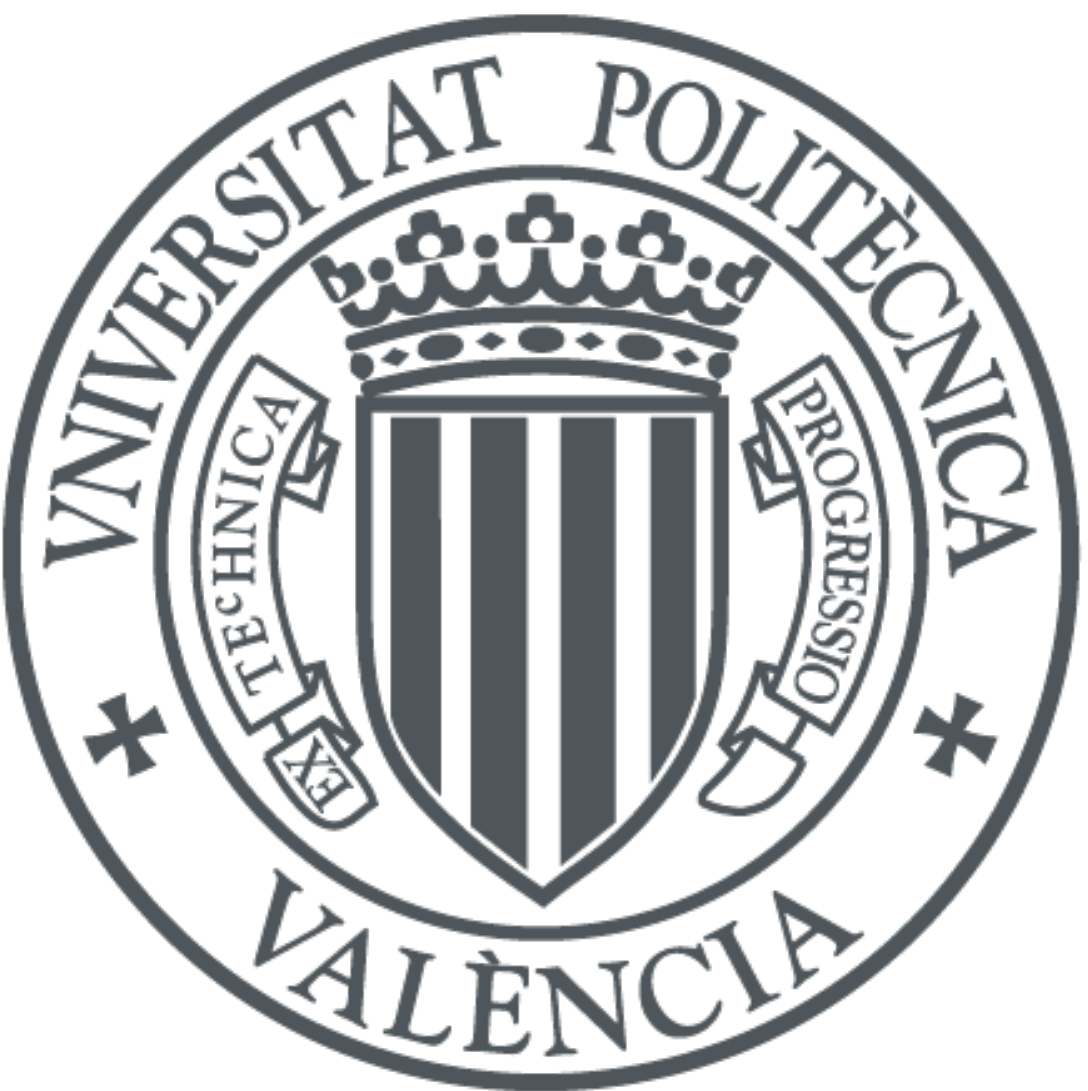

The final publication is available at

http://doi.org/10.5004/dwt.2018.21989

Copyright Taylor \& Francis

Additional Information 


\title{
APPLICATION OF ULTRAFILTRATION FOR DRINKING WATER PRODUCTION IN DECENTRALISED SYSTEMS: 20 years of the AQUAPOT project
}

\author{
J.M. Arnal*, B. García-Fayos, M. Sancho \\ ISIRYM Research Institute. Universitat Politècnica de València. Camino de Vera s/n. 46022 Valencia \\ (Spain). Phone: 0034963879633. Fax: 0034963877639. e-mails: jarnala@iqn.upv.es, \\ beagarfa@iqn.upv.es, msanchof@iqn.upv.es
}

\begin{abstract}
:
Access to drinking water is a basic human right which has become an international goal. However, despite the efforts made in the framework of the Millennium Development Goals of the United Nations, about 700 million people are still without access to an adequate source of drinking water in rural areas of developing countries, especially in Africa Sub-Saharan. The AQUAPOT project, developed by the "Instituto Universitario de Seguridad, Radiofísica y Medioambiental (ISIRYM)" of the "Universitat Politècnica de València (UPV)", both in Spain, has been focused research on the design, development and installation of decentralised drinking water systems as an alternative to existing water management systems in developing areas. AQUAPOT systems are based on ultrafiltration technology and have been successfully applied in different localities in Ecuador and Mozambique to produce safe drinking water for human consumption. The present paper describes the main actions carried out within the project AQUAPOT over the last 20 years. It describes the main features of the installed plants and the protocol to choose the best location; it also shows the main results achieved within the project, and discusses the lessons learned throughout the years in relation to the operation of the plants as well as the quality of the treated water.
\end{abstract}

Keywords: $A Q U A P O T$, ultrafiltration, water purification, decentralised systems 


\section{Introduction}

\subsection{The problem of water}

Access to drinking water is a basic human right and providing access has become an international goal. However, despite efforts made under the scope of the United NationsMillenium Development Goals, around 700 million people (9\% of the global population) remain without access to an improved source of drinking water and $32 \%$ of population lives without access to improved sanitation facilities [1]. More than 3 million people die from water-related health problems each year, and around $45 \%$ of the people on earth do not have water piped to their homes [2].

Health problems associated with water include water-borne and washing-water diseases. Waterborne diseases are predominantly due to faecal contamination of the water source and are thus strongly linked to sanitation conditions. There are about two dozen infectious illnesses, and they can be caused by viruses, bacteria, protozoa or larvae (e.g. cholera, typhoid, bacillary dysentery, infectious hepatitis, leptospirosis, giardiasis and gastroenteritis) [3]. In contrast, washing-water diseases are caused by a lack of adequate quantities of water for the proper maintenance of personal hygiene (e.g. scabies, trachoma, leprosy, conjunctivitis, salmonellosis, ascariasis, trichuriasis and hookworm) [4]. Hence, not only is water quality a cause for concern but also water quantity. In fact, according to the Joint Monitoring Programme for Water Supply and Sanitation, more than $90 \%$ of diarrheal cases are preventable through modifications to the environment, including interventions to increase the availability of clean water [5].

Improved water supplies in developing countries often present difficulties in the form of maintenance and supply to the population, caused by economic, social or political factors. In some cases, existing water treatment facilities work efficiently and produce water that is microbiologically safe, but the infrastructure for water distribution is so inadequate that recontamination can occur due to pressure drops, pipe deterioration, leaks and other deficiencies in distribution system, which leads to an increased risk of water-borne diseases [6, 7].

When drinking water is required for emergency use, such as natural disasters, some further disadvantages develop. The effectiveness of water treatment processes can be adversely affected by poor characterisation of the raw water, limitations in the availability of raw water, unsuitable catchment characteristics and other field factors [8]. If the selected water treatment technology is not adequate, the water supply targets of quantity, quality (no faecal coliforms, chlorine residual $<0.5 \mathrm{mg} / \mathrm{L}$, turbidity $<5 \mathrm{NTU}$ and no negative impact on health due to short-term consumption), coverage and continuity cannot be reached. It is worth mentioning that the transmission of water-related diseases in emergencies is likely equally due to the lack of sufficient quantities for personal and domestic hygiene and to contaminated water sources. Therefore, the quantity of water supplied should frequently be prioritised over its quality $[9,10]$.

\subsection{Drinking water technologies}

Centralised water treatment systems require a large capital investment and space for infrastructure, and involve high pumping costs. Traditionally, these systems consist of four main steps: coagulation-flocculation, sedimentation, filtration and disinfection. In urban and densely populated areas, central solutions are generally suitable for the supply, distribution and treatment of water. However, many existing cases have shown that these systems often fail to 
achieve the desired results in developing and transition countries, mostly due to political or socio-economic factors $[11,12,13,14]$. In fact, centralised structures may become technically inappropriate due to rapid urban population growth and lack of infrastructure and a wellmaintained distribution network.

In rural areas of developing countries, centralised water treatment is generally prohibitively expensive, leading to the frequent use of untreated natural water sources [15]. These sources are generally not well-protected and may contain chemical or microbial pollutants, mostly derived from a lack of adequate sanitation [13].

Decentralised systems are a more adequate, cost-effective and simpler alternative in those areas with limited economic resources, water shortages and low population densities [16]. Decentralised solutions also perform better in emergencies because they are more versatile and adaptable to the changing conditions than centralised solutions. However, these installations often have an informal character and are rarely accepted or supported by local governments [15].

These systems can be classified into point-of-use (POU) systems, when the treatment is applied at the household scale, and small-scale systems (SSS), when applied for small communities. In 2007, 18.8 million users of POU products were reported (with an average annual growth rate of $25.1 \%$ ) [17]. In emergency situations, international cooperation agencies use a combination of both POU and SSS or specific technologies to produce water of the required quality.

There are many available POU and SSS techniques with different pros and cons and varying costs and efficiencies of pollution removal. The evaluation criteria for water treatment techniques must consider several factors, and the results are specific (there is no general solution). According to Clarke and Steele, the evaluation criteria for water treatment methods used by relief agencies include: versatility to treat a wide range of feed waters, durability, reliability of operation, cost and size, ability to meet water demand and quality, ease of deployment, and ease of operation and maintenance [8]. In 2012, Loo et al. established a methodology for water technology selection that included ten factors [18]: cost, ease of employment, ease of use, environmental impact, maintenance, performance, potential acceptance, energy requirement, supply chain requirement and water throughput. In disaster relief, SSSs, that are modular, mobile or portable, are appropriate because they provide a location-specific solution.

The most widely used POU system is boiling, whose main disadvantages are the combustion requirement and the absence of residual protection. Boiling inactivates bacteria, viruses and protozoa, but the water has to be consumed immediately afterwards because microbial growth can occur without residual protection [17]. Chlorination is another low-cost POU system [19] which reduces microbiological pollution, except for cryptosporidium, but its efficiency is affected by turbidity. One of the disadvantages of this treatment is related to the hazardous byproducts that can be produced by oxidation if an appropriate pretreatment is not included [17].

Solar disinfection, known as SODIS, is a no-maintenance and ongoing-cost POU [18] that has been proved to reduce diarrheal diseases, although its efficiency also depends on turbidity [6]. Disinfection can be carried out by UV treatment as well, but the associated cost is much higher and depends on the energy price, on the UV equipment and on the process configuration. In 
contrast, filtration systems such as sand filtration and pressurised filter beds of sand or activated carbon are good at removing physical pollution but poor at virus removal.

Another type of SSS is up-flow clarifier tanks, which are based on the principle of coagulationflocculation and have been widely used in international cooperation projects. Several compact and specifically designed clarifiers have been used, such as the Oxfam Clarifier, which works with alumina and produces $5-10 \mathrm{~m}^{3} / \mathrm{h}$ of drinking water, reducing raw water turbidity values to acceptable limits (below 5 NTU). Furthermore, it has proved to be simple, robust and capable of being run by operators with no previous experience for long periods [20]. However, a lack of precise control of dosing rates-accurate jar tests are required-is a further obstacle to achieving satisfactory performance [8].

Finally, membrane-based systems represent an alternative group of decentralised water treatment processes. Several devices using microfiltration (MF), ultrafiltration (UF), nanofiltration (NF) and reverse osmosis (RO) membranes have been designed and documented, mainly UF and RO systems. Membrane-based POU and SSS products have proved to be suitable in many cases.

\subsection{Ultrafiltration based decentralised systems}

Membrane technology presents several advantages in water treatment due to its modularity, simplicity, ease of use and ability to produce a large quantity of drinking water. A wide range of membrane cut-offs are available (from MF to RO), which allows users to select the most adequate value according to the level of water pollution. This technology is attractive for developing countries because it provides absolute barriers for controlling hygiene hazards and its modular construction allows implementation on all possible scales [15]. The main disadvantages are that membranes need to be replaced every 3 to 5 years, depending on the process $[21,22]$, some chemicals are required for the cleaning steps and maintenance requires specific training.

Water treatment processes using UF membranes have achieved a 7 LRV ( $\log _{10}$ Reduction Value) reduction of coliform bacteria, a 4.4 and 7 LRV reduction of Cryptosporidium and Giardia lamblia, respectively, and a 6 LRV reduction of some viruses, such as MS2 phage [23].

Some examples of UF-based SSSs that have been successfully tested are the AQUAPOT system [3], Aqualogix $®$ (made by Garrow Ltd.), SkyHydrant ${ }^{\circledR}$ [24], AquaBoy ${ }^{\circledR}$, SkyStation ${ }^{\circledR}[22]$ and Mobil watermaker [25]. These systems differ in terms of production, water quality, pretreatment and post-treatment, costs and energy requirements.

The most relevant membrane-based POU products are Life Straw ${ }^{\circledR}$, Lifesaver ${ }^{\circledR}$ and a mobile UF system that can be transported and powered by a bicycle [26]. The Life Straw filter (made by Vestergaard) is a portable straw-like device that has a useful life of approximately 18000 litres and a cost of 0.001 US\$/litre. It removes 6-7 LRV of bacteria, 2-4.7 LRV of viruses and 3.6 LRV of protozoa with no energy requirements because it works by suction [27]. Lifesaver ${ }^{\circledR}$ has a capacity of $750 \mathrm{~mL}$ and a useful life of 6000 litres. It contains a 200-kDa UF membrane that can remove $7.5 \mathrm{LRV}$ of bacteria and more than $5 \mathrm{LRV}$ of viruses. It also includes a carbon filter that reduces the presence of chemical pollutants such as pesticides. 
Within all the decentralised systems mentioned, this work describes the main actions carried out within AQUAPOT, a research and development project based on ultrafiltration for drinking water production in developing countries.

\section{AQUAPOT: 20 years producing drinking water}

\subsection{The origins of the AQUAPOT project}

The AQUAPOT project was born in the Department of Chemical and Nuclear Engineering of the "Universitat Politècnica de València (UPV)" (Spain) in 1996; since then, the objectives of AQUAPOT continue to be developed within the research group on membranes (PROMETEO) of the "Instituto Universitario de Seguridad Industrial, Radiofísica y Medioambiente" (ISIRYM) of the UPV. Prior to the birth of the project, the research group had significant research experience in membrane processes, especially in those applied to the treatment of water, such as ultrafiltration and reverse osmosis. The trigger for the project was a collaboration between the research group and the humanitarian organisation "Fundación SER" of Ecuador, through a Spanish NGO, with the ultimate goal of improving children's health in the rural communities of the province of Azuay (Ecuador) [3].

Since 1996, the research group has worked, through the project AQUAPOT, on the development of drinking water systems based on membrane technology that can be applied in developing countries. Specifically, the project is based on the application of ultrafiltration technology through decentralised systems that allow the elimination of microbial contamination of feed water, thus producing water of suitable quality for direct human consumption.

\subsection{Preliminary tests}

Before the application of drinking water production technology, several laboratory experiments were carried out using commercial membranes and water from sewage treatment plants, reservoirs, and irrigation canals with high microbiological contamination, to validate ultrafiltration as a suitable disinfection process.

Preliminary tests were carried out using surface water with a much greater microbiological load than that expected in water in Ecuador: $300 \mathrm{cfu} / 100 \mathrm{~mL}$ (total coliform) in comparison to 50 $\mathrm{cfu} / 100 \mathrm{~mL}$ (total coliform). The plant was equipped with a spiral-wound UF polyethersulfone (PES) membrane with a cut-off of $100 \mathrm{kDa}$. These preliminary tests proved the high efficiency of the UF process in the removal of microbiological contamination, reaching rejection index values of $100 \%$ for the microbiological components analysed by the USEPA membrane filtration method [28]: faecal and total coliforms, faecal enterococcus and aerobic bacteria [29].

After this, preliminary tests continued with the study of UF plate membranes of different materials (polyethersulfone and acrylonitrile) and different cut-offs (from 10 to $100 \mathrm{kDa}$ ). These membranes were tested using waters with different microbiological loads, but all samples had greater loads than that expected in raw water in Ecuador. The rejection indexes in these tests were also $100 \%$ for the analysed microbiological components (faecal and total coliforms, and faecal enterococcus), regardless of the material or cut-off of the tested membrane. The acrylonitrile membranes showed slightly higher permeate flux values (defined as L/h of treated water per $\mathrm{m}^{2}$ of membrane area) than PES membranes. However, due to their commercial 
availability, and on the basis of their high selectivity, PES membranes have been used in the UF plants installed within the framework of AQUAPOT [30].

After selecting the appropriate UF membrane, and prior to the implementation of the project in Ecuador, a drinking water plant was designed and manufactured in accordance with the results obtained in experimental tests. This plant was completely analogous to the plant that was to be installed in Ecuador. The objective of this pilot plant was to perform a series of preliminary tests that would allow the installation to be tuned in Spain, where more resources are available to solve possible problems that could be encountered during operation, and then allow researchers to predict the performance of the facility in Ecuador. The pilot plant was built in Náquera, a small town in the province of Valencia (Spain), where the Náquera Research Centre was later established. This Centre is described in detail in section 2.5.

\subsection{Metodology of implementation}

One of the results achieved as a consequence of the experience accumulated with the AQUAPOT project is the development of the methodology to implement each facility at each location, which consists of the following steps [31]:

- Recognition of the area and identification of the main characteristics of the site where the drinking water plant is going to be implemented. This stage comprises the following actions:

- Meetings with local authorities and individuals in charge of water management at the location to inform them about the project, and listen to their suggestions.

- Signing of an agreement with the local partner for the funding of the drinking plant.

- Analysis of local water culture: awareness of the risk of consuming contaminated water, drinking water techniques used, relation between consumption and the incidence of illnesses (especially in children), habits of the population in relation to water (water collection, domestic supply, cost of water supply, etc.).

- Analysis of water resources available for the drinking water plant.

- Water quality. Samples from the possible sources are collected for analysis. The main physico-chemical and microbiological parameters measured are shown in Table 1.

- Level of protection of the water source.

- Existence of industries or natural resources that could contaminate the water source.

- Daily water consumption.

- Beneficiary population.

- Existence of drinking water treatment in the area.

- Analysis of water distribution net and water supply.

- Study of location. The main factors considered to determine the best location for the UF plant, at each site, are as follows:

- Proximity to the population (distance in metres from the location to the houses/users). The point of use of treated water must be placed at a prudent distance to assure continuous use of treated water. Maximum 100-500 metres.

- Ease of installation of pipelines and drinking water distribution system.

- Existence of hydrostatic pressure (manometric height from the point of origin of the water to the feed point of the plant). 
- Ease of access to the UF facility.

- Distance from the water's point of origin to the UF plant.

- Protection against damage and incidents.

- Plant assembly and start-up. In this step, the involvement and training of local technicians is essential. The stages considered include the following:

- Pretreatment

- Membranes

- Cleaning and maintenance

- Storage/disinfection/point of use

- Control and monitoring of plant effectiveness.

- Training of technicians.

- Awareness of potential drinking water users.

Table 1. Parameters measured to determine water quality and how they affect plant implementation

\begin{tabular}{|l|l|}
\hline Water quality parameters measured & Process affected \\
\hline $\mathrm{pH}$ & Pretreatment \\
\hline Conductivity & Selected membrane technique \\
\hline $\begin{array}{l}\text { Total coliforms } \\
\text { E. coli }\end{array}$ & Selected membrane technique \\
\hline $\begin{array}{l}\text { Suspended solids } \\
\text { Turbidity }\end{array}$ & Pretreatment \\
\hline
\end{tabular}

\subsection{Actions of AQUAPOT in Ecuador}

\subsubsection{Pucará (Azuay, Ecuador)}

In September 2004, the research project team travelled to Ecuador to install and set up the first UF plant in the town of Pucará, Azuay province (Ecuador). This first plant was financed by the UPV and through private donations. The local partners were the "SER Foundation" and the village's parish house.

After an initial study of the area, it was decided that the best place to locate the plant was the parish house, due to following advantages: ease of access to the facility, existence of manometric height (allowing operation without auxiliary pumps for water production), ease of water distribution to the population, and higher guarantee of plant integrity against any incident. Once the facility was established and operating, the parish house was in charge of the management and financing of the plant.

The plant (see Figure 1) was equipped with two UF spiral-wound modules from Hydranautics (model 4040-TFV-P100) with an effective area of $6.5 \mathrm{~m}^{2}$ each. The installed plant produced a treated water flow of 500-1000 L/hour, working at a pressure of $4 \mathrm{~kg} / \mathrm{cm}^{2}$ [32]. Approximately once a week, the membrane was washed with permeate (treated water) for cleaning. 


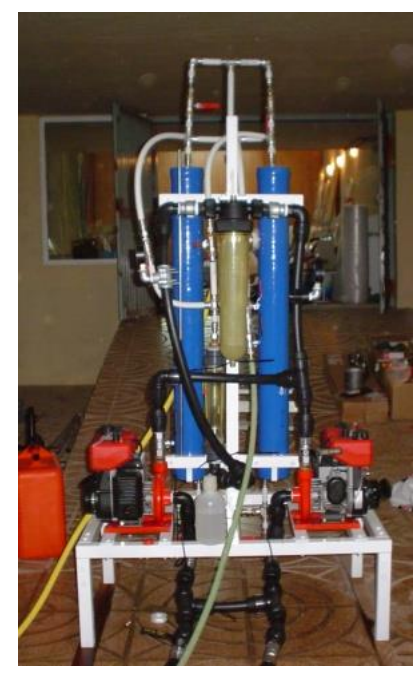

\section{Figure 1. UF plant set up in Pucará (Ecuador)}

The permeate was subjected to microbiological tests to assess membrane performance by measuring faecal and total coliforms. The first samples tested after the plant began operation showed a high removal of microbiological activity, with complete absence of coliforms [33]. Permeate was later chlorinated to preserve it from microbiological recontamination.

After several years of operation, the plant was moved to Chacras, as explained later in section 2.4.5.

\subsubsection{Girón (Azuay, Ecuador)}

In 2005, the AQUAPOT team returned to Ecuador, to the town of Girón, also in the province of Azuay, to install a new UF plant. This plant was financed by the Náquera town hall (province of Valencia, Spain). The local partner that collaborated on the project was the "SER Foundation", the same partner that participated in the plant located in Pucará.

In this case, after the preliminary study of the area, it was decided to install the plant next to a food microenterprise that provides milk and meat to the population of Girón. Once built and in operation, the microenterprise was in charge of managing the plant and financing the treated water used for the microenterprise's productive process, but the plant was the property of the "SER Foundation".

The plant (see Figure 2) was equipped with a UF hollow-fibre module from Hydranautics (model Hydracap60) with an effective area of $46 \mathrm{~m}^{2}$. The installed purification plant had a throughput of 2000-2500 L/h. The drinking water produced in the plant was used to supply the micro-industry $(1500 \mathrm{~L} / \mathrm{h})$ and the population $(500 \mathrm{~L} / \mathrm{h})$. The plant worked by hydrostatic pressure (water was supplied from a ravine located at $700 \mathrm{~m}$ altitude) and did not require pumping for ultrafiltration. Approximately once a week, the membrane is backwashed with permeate for cleaning purposes. 


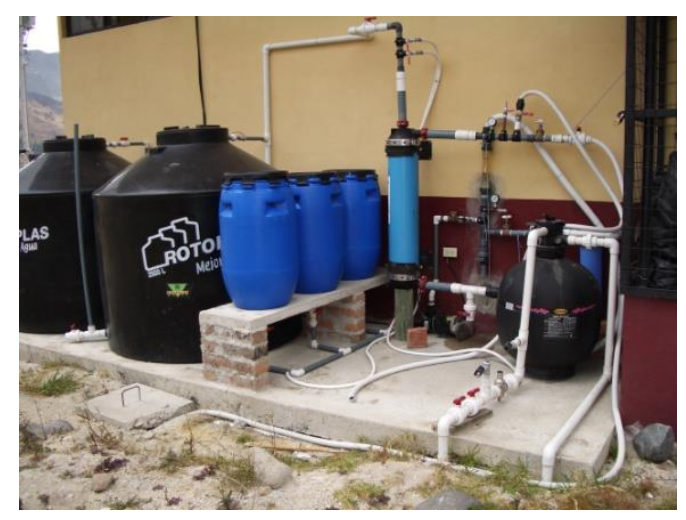

Figure 2. UF plant set up in Girón (Ecuador)

To assess the efficiency of the treatment, permeate was subjected to microbiological tests to determine the content of thermotolerant and total coliforms using the method SM 9221E. The results reported after several months of operation proved the high efficiency of UF in the removal of coliforms, indicating their complete absence [34], and showed that ultrafiltered water is completely suitable for use in the microenterprise and for human consumption [35]. Permeate was later chlorinated to preserve it from microbiological recontamination.

Thanks to its good quality, the ultrafiltered water was authorized by the Ecuadorean government for meat and dairy processing.

In 2009, the microenterprise came under new ownership, and the enterprise's operating principles were substantially changed. The UF plant was replaced by a NF plant owned by the microenterprise.

\subsubsection{Santa Isabel (Azuay, Ecuador)}

In the AQUAPOT team's first stay in Ecuador, they contacted the humanitarian organisation "Mensajeros de la Paz" of Ecuador, which works improving the situation of children in the rural communities of the province of Azuay (Ecuador). As a result of this contact, collaboration with that local partner within the framework of the AQUAPOT project began, which resulted in 2005 in the installation of a UF plant in the canton of Santa Isabel (Ecuador). This plant was financed by the UPV and through private donations.

After the preliminary study of the area, it was decided that the best place to locate the drinking water plant was the school run by "Mensajeros de la Paz" in Santa Isabel. This site was chosen for the following reasons: proximity to the population, ease of access to the facility (which helps to quickly solve problems that may arise during operation), existence of a water tank with pumping equipment (which allows the continuous supply of water to the treatment plant), ease of distribution of treated water to the population, and guarantee of the plant integrity against any incident.

Once built and in operation, the plant was managed by the local parish house. The plant was the property of the municipality and the parish house, which jointly financed the plant operation.

The plant is completely analogous to that installed at Pucará, and it is also equipped with two UF spiral-wound modules from Hydranautics (model 4040-TFV-P100). The installed water 
treatment unit produces a flow of ultrafiltered water of 500-1000 L/hour, working at a pressure of $4 \mathrm{~kg} / \mathrm{cm}^{2}$. Approximately once a week, the membrane is washed with permeate.

The drinking water produced directly supplied 600 students of the school and indirectly supplied the population of Santa Isabel (18000 inhabitants) [36]. Figure 3 shows a photograph of the plant installed in Santa Isabel.

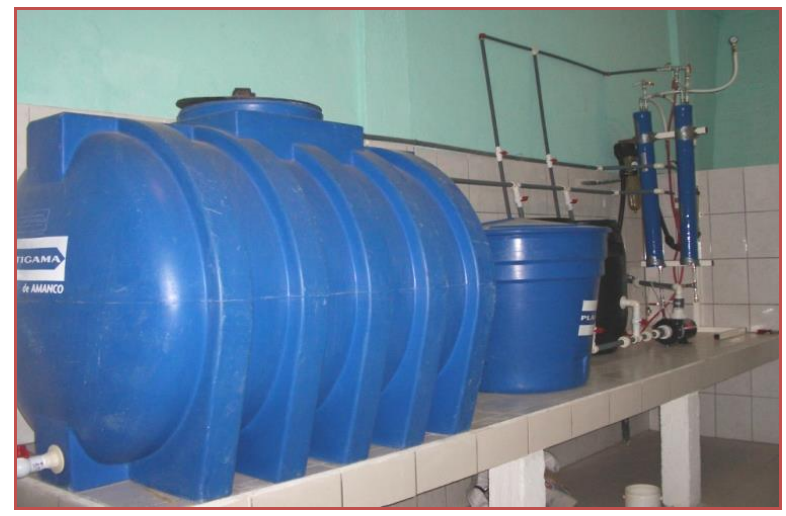

Figure 3. UF plant set up in Santa Isabel (Ecuador)

To assess membrane performance, in addition to turbidity and $\mathrm{pH}$, microbiological tests of the permeate were carried out. Total coliforms were determined by culture tests. The results of all microbiological tests showed a complete absence of total coliforms [34].

In 2008, after the municipality of Santa Isabel made the necessary improvements to the pipe system, the plant was moved to La Granja, a boarding school with 50-60 mentally disabled residents that is managed by "Mensajeros de la Paz", as is described in the following section.

\subsubsection{La Granja (Azuay, Ecuador)}

In 2008, the plant previously installed in Santa Isabel was moved to the "Granja Terapéutica Santa María de Quillosisa", a centre managed by "Mensajeros de la Paz", also located in the province of Azuay (Ecuador). The facility is a boarding school for people with disabilities (50100 patients) and also includes an adjoining farm. In addition, the centre produces scents and soaps using extraction techniques, which are then marketed through "Mensajeros de la Paz". The water produced by the UF plant is used by patients and staff at the centre and also supplies water to the production system for manufacturing essences and soaps. Figure 4 shows a photograph of the plant installed at La Granja. 


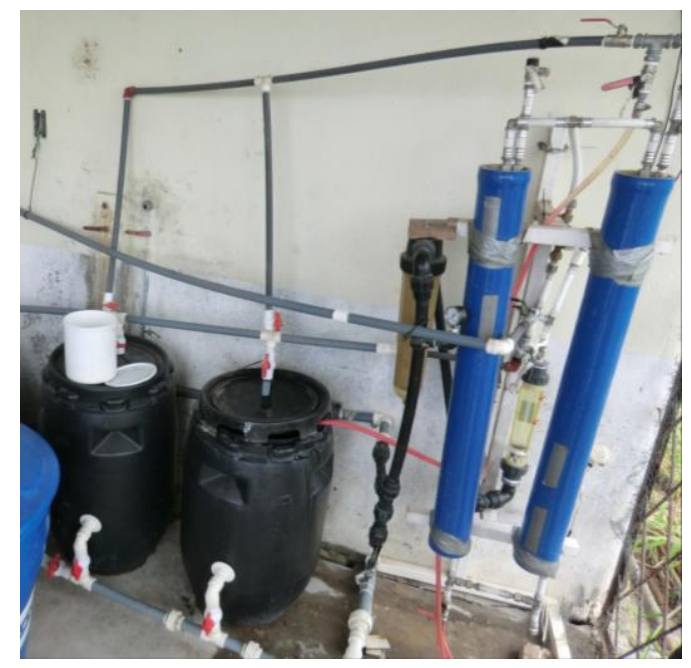

Figure 4. UF plant set up in La Granja (Ecuador)

The efficiency of the plant is assessed every 1-3 months, as in the other cases, through culture tests of total coliforms. Analogously to the rest of the facilities, the permeate is later chlorinated to preserve it from microbiological recontamination.

In 2012, thanks to the good quality of the water produced by the UF plant and its suitability for food use, the centre of La Granja was also authorised for the production of tinned fruit.

At present, this plant is still in operation, and the produced permeate is used to supply the boarding school, as well as to produce soaps and tinned fruit.

\subsubsection{Chacras (Azuay, Ecuador)}

In 2011, part of the AQUAPOT team visited the province of Azuay (Ecuador) to check the status and operation of the three previously installed plants, in addition to other objectives. In the visit to Pucará they found that the local installation was not in operation. This was because in 2008, the local leadership changed, and the water treatment plant was moved from the original location to a warehouse in the same town. As a consequence, the UF treatment plant was moved to Chacras, in the province of El Oro (Ecuador), where "Mensajeros de la Paz" manages several schools and centres lacking good-quality water. This plant is now managed by "Mensajeros de la Paz", which is also in charge of financing the operating costs.

The operating conditions are analogous to those at the previous location (see section 2.4.1), including cleaning protocols. Assessments of plant performance were carried out by measuring turbidity and $\mathrm{pH}$, as well as by performing culture tests of total coliforms. To date, the results have shown a complete absence of coliforms. As at the other sites, the permeate is chlorinated after filtration to prevent water recontamination.

At present, AQUAPOT is developing a project for the installation of several UF plants in the near future to expand the water supply to different locations in the province of El Oro. 


\subsection{Náquera Research Centre (CIN)}

In parallel with the installation of the plants in Ecuador, the Náquera Research Centre (CIN, in Spanish) was created in Spain, thanks to the "Agreement of collaboration for the purification of water by membrane technology and implementation in Iberoamerica-Ecuador" signed between the "Ayuntamiento de Náquera" (Valencia) and the "Universitat Politècnica de València".

The creation of the Náquera Research Centre and its incorporation in the AQUAPOT project are intended to facilitate the diagnosis of the behaviour of the membranes installed in Ecuador to prevent possible incidents attributable to incorrect operation of the facility, which would negatively affect the quantity and quality of the treated water. Specifically, the CIN was created with the following goals:

- Simulate the operating conditions of UF plants installed in Ecuador, as well as the level of microbiological contamination of the surface water with which they work.

- Simultaneous operation of the plants installed at the CIN and those installed in Ecuador, with the aim of solving operation-caused incidents in Ecuador, in a coordinated way.

- Performance of long-term tests at the facilities designed and located at the CIN, using water with high microbiological contamination, to evaluate their behaviour after operation under severe conditions.

In the Náquera Research Centre, there is a filtration pretreatment system and two drinking water plants based on membrane technology, similar to those installed in Ecuador. The water used for the tests comes from a 5-million-litre irrigation pond nearby (see Figure 5), which has a microbiological contamination exceeding that of surface water in Ecuador [37].

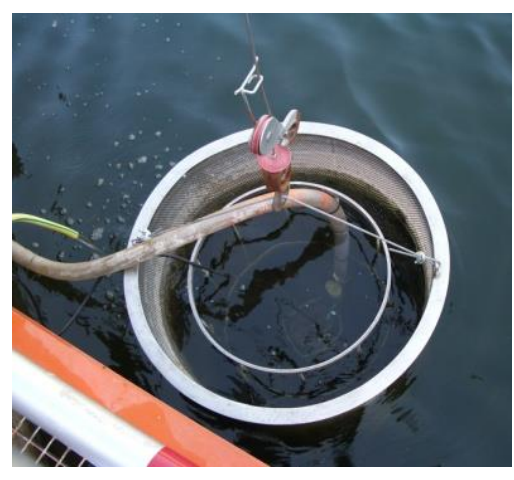

Figure 5. Catchment point with double filter in the Náquera Research Centre (CIN)

In addition, the design of membrane-cleaning protocols has been carried out in the CIN, as well as research on the development of modular systems for water pretreatment that precede the ultrafiltration plant. In the Centre, membrane fouling is accelerated by treating surface water with a high fouling potential. After fouling, different cleaning protocols are studied, with the following general sequence: washing with permeate, chemical cleaning and additional washing. The chemical products tested are those that are more easily found in the developing areas where UF plants are built [38].

The Náquera Research Centre was running successfully until 5 years ago. However, it is no longer in operation due to the deep financial crisis that affected our country, which made it difficult or impossible to access adequate economic resources to maintain small research centres 
such as this one. Currently, the CIN is being dismantled so that it can be modified and reestablished.

\subsection{Actions of AQUAPOT in Mozambique}

As a result of the successful performance of the drinking water plants, we contacted several individuals working in developing regions with poor water quality. One of the contacts was Father Vicente Berenguer, who runs the "Christian community of San Jose" in the town of Ressano García, in the province of Maputo (Mozambique). Collaboration from this contact resulted in the expansion of the AQUAPOT project in Mozambique, whose actions are described below.

\subsubsection{Escola Primaria, Ressano García (Maputo, Mozambique)}

In 2007, the first UF plant was installed in Ressano García, Maputo province (Mozambique). This first plant for Mozambique was financed by the UPV and by the town halls of Náquera and Valencia (Spain). The local partner that cooperated in the project was the parish house of Ressano García (province of Maputo, Mozambique).

After a preliminary study of the area, it was decided to install the plant next to the Escola Primaria to supply the 1000 children who study there, through 6 points of distribution. The plant is the property of the Escola Primaria, and it is jointly managed and financed by it and the parish house.

The plant, which is analogous to one installed in Ecuador, is equipped with two UF spiralwound modules from Hydranautics (model 4040-TFV-P100) with an effective area of $6.5 \mathrm{~m}^{2}$ each, and a production capacity of 500-1000 L/h (see Figure 6). The cleaning protocol consists of washing the membrane with ultrafiltrated water.

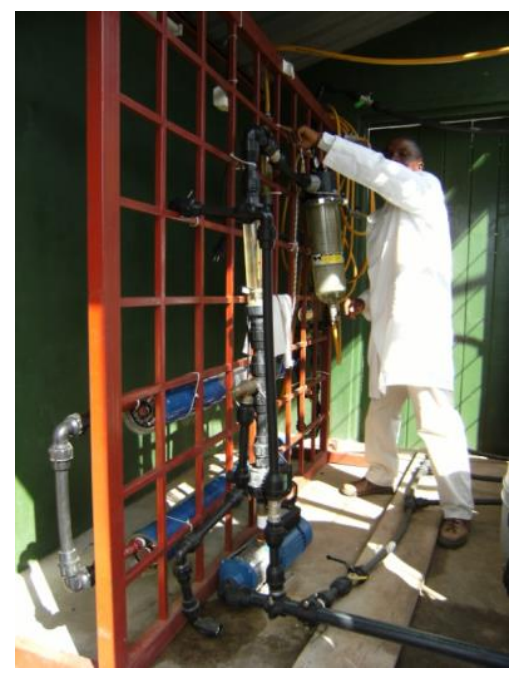

Figure 6. UF plant installed at the Escola Primaria of Ressano García (Mozambique)

Total coliform tests were performed by using the ColitagTM kit, which uses a semiquantitative test to indicate the presence or absence of total coliform bacteria, faecal coliform bacteria and Escherichia coli. This test is carried out every 1-3 months. Results reported after 4 years of operation showed the high efficiency of the UF process in the removal of total coliforms, 
indicating their complete absence. Only some samples taken at the point of use during the summer season showed a slight presence of microbiological contamination associated with coliforms, which resulted in the introduction of a post-treatment stage that improved water quality [39]. As in the other cases, permeate is chlorinated to prevent microbiological recontamination of the water.

\subsubsection{Health Centre, Ressano García (Maputo, Mozambique)}

In 2008, a new project began within AQUAPOT with the local-partner collaboration of the parish house of Ressano García and the neighbouring health centre. The project involved installing a water treatment unit to supply people at the health centre of Ressano García. This plant was installed in 2010, thanks to the financing of the UPV and the town halls of Náquera and Valencia (Spain). The plant is the property of the parish house and the health centre, which jointly finance and manage the operation for water production.

The site chosen for the drinking water unit was close to the health centre water storage tanks because there was a water storage pond there, as well as adequate pipes. Furthermore, the site is at a slightly elevated altitude, which makes the distribution of water by gravity easier, and the unit is easily accessible by the population.

Unlike the ultrafiltration plants installed thus far, in this case, a portable system (a container) was chosen because of the possibility that in the not-too-distant future, the border between Mozambique and South Africa may be modified, causing consequent modifications in the pipes. A portable system, however, could easily be moved to a new location without incurring high costs, allowing the continuous and immediate production of water. Figure 7 shows a photograph of the container-based UF plant.

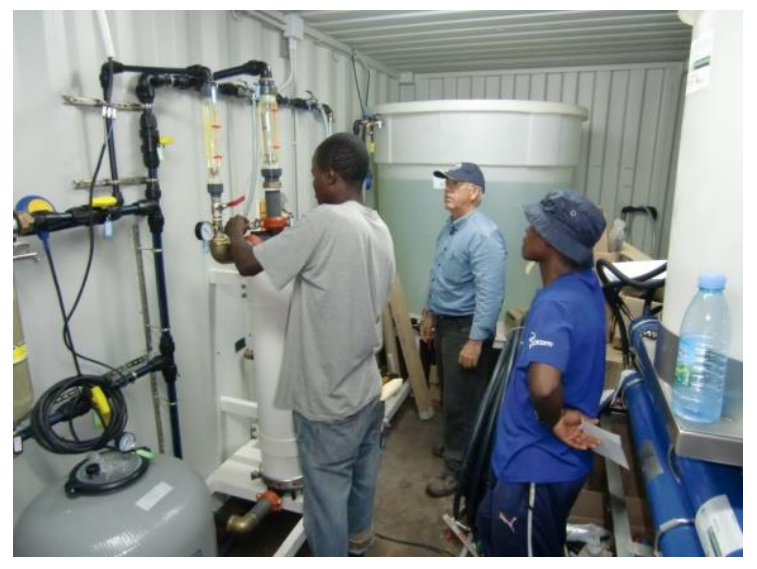

\section{Figure 7. UF plant installed at the Health Centre of Ressano García (Mozambique)}

The UF plant is similar to that installed at the microenterprise of Girón in Ecuador. It is equipped with a UF hollow-fibre module from Hydranautics (model Hydracap60), with an effective area of $46 \mathrm{~m}^{2}$, and it has a throughput of $45 \mathrm{~m}^{3} /$ day $(2000 \mathrm{~L} / \mathrm{h})$ of treated water, working at a pressure of $2 \mathrm{~kg} / \mathrm{cm}^{2}$. The supply of treated water to the Helth Centre of Ressano Garcia directly benefits 1500 people, including hospital patients, health personnel and students from the Esperança School, and indirectly benefits the population of Ressano Garcia (10000 inhabitants) [40]. 
To assess plant performance, microbiological tests of the permeate are carried out every 1-3 months with the ColitagTM kit, which uses a semiquantitative test to indicate the presence or absence of total coliform bacteria, faecal coliform bacteria and Escherichia coli. This test is carried out every 1-3 months. To date, the results have shown the complete absence of coliforms [40]. Regardless, the permeate is subsequently chlorinated to prevent water recontamination.

Periodically, drinking water production stops to execute plant maintenance. The sand filter is backwashed, the mesh microfilter is washed, and cleaning-in-place (CIP) of the UF membrane is performed. CIP consists of two steps: recirculation of the cleaning solution through the UF module and rinsing with drinking water. Once CIP has been completed, the plant can produce drinking water again.

During more than 15 years of operation of the AQUAPOT project, we have acquired extensive experience in all aspects concerning the project, from administrative management to the technical aspects of the facilities and, of course, the implementation of the facilities at their respective locations. This section is intended to summarise the main lessons learned as a result of this experience, which have been useful in improving the project's phases of operation and suggesting future areas of development.

A) Identification of the area, analysis of available water resources and study of location

- Catchment water nearly always contains microbiological contamination, regardless of its origin (pipelines, drinking water plant, stream). Protecting the aquifer to prevent it from being contaminated by humans, animals or spills is necessary to guarantee the maximum quality of the raw water.

- The installation of a new water catchment system separated from the existing catchment point is preferable in order to interfere with the existing system as little as possible. The feeding of the plant was discontinuous when the existing pipeline system was used. Long stops of up to 21 days occurred, which jeopardises the installation lifetime in the medium term.

- Operating the plant's feeding pumps by hydrostatic pressure without having to depend on power is preferable in all cases. This guarantees more independence and autonomy to the system in areas with continuous cutoffs and allows continuous operation with no power cost.

- The plant must be placed in an enclosure and its access must be controlled by the local partner to guarantee the plant's integrity. Some plants were damaged and some pieces went missing when the plant was accessible.

- Several water access points, such as faucets, must be installed to provide the population access to the treated water. This access must be controlled by the local partner.

B) Plant assembly and start-up 
The ability to acquire material locally is important for the operation to maintain continuity and allow replacement parts to be easily found if needed. Regarding the plant, the experience from 15 years of the project indicates the following:

- Pretreatment. Catchment water quality varies considerably from day to day (turbidity, suspended matter and microbiological contamination), especially during the rainy season. A multiple-layer filtration system must be set up before the plant inlet. Experience has shown that a suitable sequence is coarse filtration with metal grids of different pore sizes, followed by a 300-micron sand filter and a 50-micron microfilter. When the water is obtained from a pipeline system (usually obsolete and with continuous leaks), at least a 300-micron sand filter and 50-micron microfilter are necessary. This pretreatment ensures that the water feeding the membrane meets the quality standards required by the technical specifications of the membrane manufacturer, thus preserving the membrane's lifetime.

- Membranes. Spiral-wound membranes have been used in this project with good results. Subsequently, hollow-fibre membrane modules, which allow higher values of permeate flux and higher recovery rates, were commercialised, and these are the membranes currently installed in the plants.

- Storage, disinfection and point of use. Ultrafiltered water must be chlorinated to avoid the recontamination of the produced water, especially in areas with high temperatures (higher than $40{ }^{\circ} \mathrm{C}$ ) and with long storage times. Because, in some cases, users have refused to consume treated water due to the chlorine taste, a UV unit was added to allow water disinfection without any additional taste. This guarantees that water is completely disinfected. However, if collection receptacles are not clean enough, there is a risk of recontamination of water in the home. For this reason, we suggest the use of chlorine in the storage of water in homes.

C) Training of technicians

Another important stage for the success of the project is the training of local technicians, both in the performance of water-related tasks, such as the subsequent conditioning of treated water, and in the maintenance and cleaning of the installation. The local partner should choose the local technicians to be trained in the assembly, operation and maintenance of the plant. This will guarantee the correct operation of the installation once the AQUAPOT team has left the area. No previous technical education is required for plant assembly. However, the technicians must have a reliable link with the local partner, and they should be integrated within the community to guarantee the operation of the plant in the medium term. The selection at least of 4 people is recommended. The local partner must be responsible for monitoring these individuals.

D) Control and monitoring of plant effectiveness

Fluid communication with the AQUAPOT team is very useful for solving problems and make changes that would take place during plant operation.

E) Awareness in potential drinking water users 
Another key point for the success of the installed plant is the potential consumers' awareness of the facts regarding treated water, particularly their awareness of the risks of consuming contaminated water and the benefits of consuming water from the UF plant. The users should know the benefits of consuming the treated water, and the local partners must facilitate the implementation of the technology. The positive awareness of the population is effective and necessary to guarantee the success of the action in the medium term, especially in children, as they are the main beneficiaries and the future of the community.

F) Sustainability and financing

Plant sustainability (operation and maintenance) depends either on municipal financing or on the local partner. Users should pay a reasonable price for the drinking water, proportional to the amount consumed; this pricing method is a fair and sustainable approach to financing.

After over 15 years of existence and despite some failures and many efforts that have not always achieved the desired objectives, we can say that the AQUAPOT project has been, and continues to be, a success from multiple perspectives. Technically, it has contributed to the development of UF drinking water plants, having gradually optimised the combination of pretreatments, UF membranes and treated water conditioning using research and field experience. UF is a simple and reliable technique for obtaining drinking water from raw water sources in decentralised use. Moreover, it has proved to be very effective in removing microbiological content from different contamination loads. Some important stages implemented to improve treatment have included microfiltration pretreatment, to stabilise the microbiological content of the UF feed, and permeate chlorination during storage, to prevent it from later recontamination.

From the perspective of cooperation, the experience accumulated over these 20 years has led to the definition of the most suitable conditions for locating and implementing each plant. Most of the critical issues within this process are related to the participation of both local and municipal partners, the political stability of the area, the professional commitment of the operators and potential users' awareness of the benefits of drinking treated water. Sustainability of the project in the medium term is guaranteed if these critical issues are addressed.

\section{Acknowledgments}

The authors would like to express their gratitude to people from Ecuador and Mozambique for their collaboration in this work, as they are the main reasons for growth and development; to the local authorities of the towns involved in the implementation of the project; to José Luis Sánchez from "Mensajeros de la Paz", Father José Miguel Uzhca, "Fundación SER" and the "Association for Cooperation with Ecuador" (ACOEC) for their involvement in the actions of AQUAPOT in Ecuador; to Father Vicente Berenguer Llopis because he involved institutions, municipalities and training centres as receptors and beneficiaries of the actions of AQUAPOT in Mozambique; to D. Manuel Escolano Puig because he has always believed in AQUAPOT; to the "Ayuntamiento de Valencia", the "Generalitat Valenciana", and the "Ayuntamiento de Náquera" (Valencia) for their support of the project; to people from the "Universidad Técnica Particular de Loja" (UTPL) because they actively participated in the practical implementation of 
the project; to the "Instituto Nacional del Agua" of Buenos Aires (INA) for its support and encouragement to continue; to the lecturers of the Chemical and Nuclear Engineering Department and the researchers of the ISIRYM, both at the "Universitat Politècnica de Valencia", for their support and dedication to AQUAPOT; and especially to the families and researchers who support the project in an indirect way because they transformed the project from an idea to a reality.

\section{References}

[1] World Health Organization (2015). Key facts from JMP 2015 report. From: http://www.who.int/water_sanitation_health/monitoring/jmp-2015-key-facts/es/

[2] F. Macedonio, E. Drioli, A.A. Gusevd, A. Bardowe, R. Semiat and M. Kuriharag, Efficient technologies for worldwide clean water supply, Chem. Eng.Process., 51 (2012) 2-17. doi: https://doi.org/10.1016/j.cep.2011.09.011

[3] J. M. Arnal, M. Sancho, G. Verdú and J. Lora, Design of a membrane facility for water potabilization and its application to Third World countries, Desalination, 137 (2001) 63-69. doi: https://doi.org/10.1016/S0011-9164(01)00205-3

[4] N.J. Ashbolt, Microbial contamination of drinking water and disease outcomes in developing regions, Toxicology, 198 (2004) 229-238.

doi: https://doi.org/10.1016/j.tox.2004.01.030

[5] WHO/UNICEF. (2005) WATER FOR LIFE - Making it happen, Joint Monitoring Programme for Water Supply and Sanitation, ISBN 92-4-1562-935. From: http://www.who.int/water_sanitation_health/monitoring/jmp2005/en/

[6] M.D. Sobsey, Managing Water in the Home: Accelerated Health Gains from Improved Water Supply. Water, Sanitation and Health. Department of Protection of the Human Environment, World Health Organization, 2002.

[7] E.J. Lee and K.J. Schwab, Deficiencies in drinking water distribution systems in developing countries, J. Water Health, 3(2) (2005) 109-127.

[8] B.A. Clarke and A. Steele, Water treatment systems for relief agencies: The on-going search for the 'Silver Bullet', Desalination, 248 (2009) 64-71.

doi: https://doi.org/10.1016/j.desal.2008.05.039

[9] M. Smith and R. Reed, Water and sanitation for disasters, Trop. Doct., 21(1) (1991) 30-37. doi: $0.1177 / 00494755910210 S 108$

[10] The Sphere Project. Humanitarian Charter and Minimum Standards in Disaster Response. Practical Action. ISBN 978-1-908176-00-4. From: http://www.ifrc.org/PageFiles/95530/TheSphere-Project-Handbook-20111.pdf, 2011. 
[11] M.H. Zerah, Household strategies for coping with unreliable water supplies: the case of Delhi, Habitat Int., 24 (2000) 295-307. doi: 10.1016/S0197-3975(99)00045-4

[12] A.G. Kyessi, Community-based urban water management in fringe neighbourhoods: the case of Dar es Salaam, Tanzania, Habitat Int., 29 (2005) 1-25. doi: 10.1016/S01973975(03)00059-6

[13] A. Gadgil, Drinking water in developing countries, Annu. Rev. Energ. Env., 23 (1998) 253-286. doi: 10.1146/annurev.energy.23.1.253

[14] S.R. Basu and H.A.C. Main Calcutta's water supply: demand, governance and environmental change, Appl. Geogr., 21 (2001) 23-44. doi: https://doi.org/10.1016/S01436228(00)00018-7

[15] M. Peter-Varbanets, C. Zurbrügg, C. Swartz and W. Pronk, Decentralized systems for potable water and the potential of membrane technology, Water Res., 43 (2009) 245-265. doi: 0.1016/j.watres.2008.10.030

[16] M.A. Massoud, A. Tarhini and J. A. Nasr, Decentralized approaches to wastewater treatment and management: Applicability in developing countries, J. Environ. Manage., 90 (2009) 652-659. doi: https://doi.org/10.1016/j.jenvman.2008.07.001

[17] World Health Organization, Guidelines for drinking water quality. ISBN 978924154815 1. From: http://apps.who.int/iris/bitstream/10665/44584/1/9789241548151_eng.pdf, 2011.

[18] S. Loo, A.G. Fane, W.B. Krantz and T. Lim, Emergency water supply: A review of potential technologies and selection criteria, Water Res., 46 (2012) 3125-3151. doi: https://doi.org/10.1016/j.watres.2012.03.030

[19] T. Clasen, S. Cairncross, L. Haller, J. Bartram and D. Walker, Cost-effectiveness of water quality interventions for preventing diarrhoeal disease in developing countries, J. Water Health, 5 (2007) 599-608. doi: 10.2166/wh.2007.010

[20] C.C. Dorea, R. Luff, A. Bastable and B.A. Clarke, Up-flow Clarifier for emergency water treatment, Water Environ. J., 23 (2009) 293-299. doi: 10.1111/j.1747-6593.2008.00142

[21] S.A. Avlonitis, K. Kouroumbas and N. Vlachakis, Energy consumption and membrane replacement cost for seawater RO desalination plants, Desalination, 157 (2003) 151-158. doi: https://doi.org/10.1016/S0011-9164(03)00395-3

[22] A. Fenu, W. De Wilde, M. Gaertner, M. Weemaes, G. de Gueldre and B. Van De Steene, Elaborating the membrane life concept in a full scale hollow-fibers MBR, J. Membrane Sci., 421-422 (2012) 349-354. doi: https://doi.org/10.1016/j.memsci.2012.08.001

[23] World Health Organization. Laboratory biosafety manual de bioseguridad en el laboratorio. Third edition. From: http://www.who.int/csr/resources/publications/biosafety/Biosafety7.pdf, 2004. 
[24] R. Butler, Skyjuice technology impact on the U.N. MDG outcomes for safe affordable potable water, Desalination, 248 (2009) 622-628.

doi: https://doi.org/10.1016/j.desal.2008.05.111

[25] L. Groendijk and H.E. De Vries, Development of a mobile water maker, a sustainable way to produce safe drinking water in developing countries, Desalination, 248 (2009) 106-113. doi: https://doi.org/10.1016/j.desal.2008.05.044

[26] Y. He, Transportable membrane system produces drinking water, Membrane Technol., 8 (2009) 8-9. doi: 10.1016/S0958-2118(09)70163-6

[27] LifeStraw. Summary of Test Data Received from the University of North Carolina School of Public Health, Department of Environmental Sciences and Engineering. From: http://www.lifestraw.com.br/ls-p-testresult.pdf, 2007.

[28] USEPA Method 1604. Total Coliforms and Escherichia coli in Water by Membrane Filtration Using a Simultaneous Detection Technique (MI Medium). US Environmental Protection Agency Office of Water. Washington D.C., 2002.

[29] J.M. Arnal, M. Sancho, G. Verdú, J. Lora, J. Gozálvez, J. Ibáñez, I. Febrer and I. Terrades, Design and construction of a water potabilization membrane facility and its application to the third world countries. Preliminary tests, Desalination, 145 (2002) 305-308. doi: https://doi.org/10.1016/S0011-9164(02)00427-7

[30] J.M. Arnal, M. Sancho, G. Verdú, L. Lora, J.F. Marín and J. Cháfer, Selection of the most suitable ultrafiltration membrane for water disinfection in developing countries, Desalination, 168 (2004) 265-270. doi: https://doi.org/10.1016/j.desal.2004.07.007

[31] J.M. Arnal, M. Sancho, B. García-Fayos, J. Lora and G. Verdú, UF-designed facility location protocol for a potable water treatment in developing countries, Desalination, 200 (2006) 322-324. doi: https://doi.org/10.1016/j.desal.2006.03.322

[32] J.M. Arnal, M. Sancho, B. García-Fayos, G. Verdú and J. Lora, Aplicación de la ultrafiltración para la potabilización de agua en países en vías de desarrollo, V Congreso Iberoamericano en Ciencia y Tecnología de membranas (CITEM 2005), Valencia (Spain), 2005.

[33] J.M. Arnal, B. García-Fayos, M. Sancho, J. Lora and G. Verdú, Water potabilization in developing countries: membrane technology and natural coagulants, Desalination, 200 (2006) 325-326. doi: https://doi.org/10.1016/j.desal.2006.03.321

[34] J.M. Arnal, M. Sancho, B. García-Fayos, J. Lora and G. Verdú, Aquapot: UF real applications for water potabilization in developing countries. Problems, location and solutions adopted, Desalination, 204 (2007) 316-321. doi: https://doi.org/10.1016/j.desal.2006.02.037

[35] J.M Arnal, B. García-Fayos and M. Sancho, Application of membrane technologies to high quality process water obtention for food industry in developing countries, International Conference on Food Innovation (FoodInnova 2010), Valencia (Spain), 2010. 
[36] J.M. Arnal, B. García-Fayos, M. Sancho, J. Lora and G. Verdú, AQUAPOT: Aplicación real de una instalación potabilizadora basada en la tecnología de membranas. El caso de Santa Isabel (Ecuador), X International Congress on Project Management and Engineering (AEIPRO 2006), Valencia (Spain), 2006.

[37] J.M. Arnal, B. García-Fayos, M. Sancho, J. Lora, G. Verdú and A. Antolí, AQUAPOT: Descripción del Centro de Investigación de Náquera (CIN). Apoyo en la aplicación de instalaciones de potabilización mediante tecnología de membranas, X International Congress on Project Management and Engineering (AEIPRO 2006), Valencia (Spain), 2006.

[38] J.M. Arnal, B. García-Fayos, M. Sancho and G. Verdú, Ultrafiltration membrane cleaning with different chemical solutions after treating surface water, Desal. Water Treat., 7(3) (2009) 198-205. doi: http://dx.doi.org/10.5004/dwt.2009.709

[39] J.M. Arnal, B. García-Fayos, M. Sancho, G. Verdú and J. Lora, Design and installation of a decentralized drinking water system based on ultrafiltration in Mozambique, Desalination, 250 (2010) 613-617. doi: https://doi.org/10.1016/j.desal.2009.09.035

[40] J.M. Arnal, B. García-Fayos, A. Giménez and M. Sancho, AQUAPOT: Instalación de una unidad potabilizadora móvil basada en tecnología de membranas en el Hospital de Ressano Garcia (Mozambique), XVI International Congress on Project Management and Engineering (AEIPRO 20012), Valencia (Spain), 2012. 